\title{
Nutrient composition of the Indonesian sago grub (Rhynchophorus bilineatus)
}

\author{
Realm Köhler ${ }^{1,2}\left(\mathbb{D} \cdot\right.$ Andrea Irias-Mata $^{1} \cdot$ Euniche Ramandey $^{3} \cdot$ Ratna Purwestri $^{1} \cdot$ Hans Konrad Biesalski $^{1}$
}

Received: 9 July 2019 / Accepted: 4 February 2020 / Published online: 18 February 2020

(C) The Author(s) 2020

\begin{abstract}
The sago grub (Rhynchophorus bilineatus) [Montrouzier, Coleoptera, Dryophthoridae] is a local delicacy in the Papua Province in Indonesia. In this study, the nutrient content of the edible insect was measured using chromatographic and spectrometric methods. The results showed that it contains $10.39 \mathrm{~g}$ protein and $17.17 \mathrm{~g}$ oil $/ 100 \mathrm{~g}$ fresh weight. The sago grub meets the FAO/ WHO requirements of $40 \%$ essential amino acids and a 0.60 ratio between essential to non-essential amino acids. Its limiting amino acid is methionine + cysteine. The major fatty acids found in the sago grub are palmitic (42\%), oleic (45\%), and linoleic (3\%) acids. Although vitamin E is exclusively produced by photosynthetic organisms, a gram of sago grub oil contains $51 \mu \mathrm{g}$ vitamin E, which is composed mainly of tocopherols $(92 \%)$. In contrast with palm oil, the sago grub oil contains $\delta$-tocopherol $(0.12 \mu \mathrm{g} / \mathrm{g}$ oil $)$, and a significantly high amount of $\beta$-tocopherol ( $3.85 \mu \mathrm{g} / \mathrm{g}$ oil). It is a source of zinc and magnesium and contains safe levels of heavy metals. Based on these nutritional properties, the Indonesian sago grub can be considered as a good source of nutrients, and its propagation and utilization should be encouraged especially in other areas of Indonesia and maybe in neighboring countries where they are also endemic, and where malnutrition is prevalent. The consumption of edible insects should be considered as a component of dietary diversification - a sustainable way of alleviating the nutritional status of the population.
\end{abstract}

Keywords Edible insects $\cdot$ Dietary diversification $\cdot$ Nutritional profiling $\cdot$ Micronutrients $\cdot$ Vitamin E

\section{Introduction}

Indonesia has the world's fourth largest population with more than 260 million people, and is the largest country in Southeast Asia with a land area of $1,904,569 \mathrm{~km}^{2}$ (UN Department of Economic and Social Affairs, Population Division 2017). It is rich in natural resources but is plagued by high levels of acute and chronic malnutrition, together with an increasing rate of childhood obesity (UNICEF Indonesia 2018), a situation common in members of the Association of Southeast Asian Nations (ASEAN). In the fight against malnutrition, there are three possible options: fortification,

Realm Köhler

Alis.R@uni-hohenheim.de

1 Institute of Nutritional Science (140a), University of Hohenheim, Garbenstrasse 30, 70599 Stuttgart, Germany

2 College of Industrial Technology, Aklan State University, Roxas Avenue Ext., 5600 Kalibo, Aklan, Philippines

3 University of Cenderawasih, Jayapura, Papua, Indonesia supplementation and dietary diversification. Among the three, dietary diversification is viewed as most sustainable. In promoting this option, the FAO encourages people to utilize indigenous fruits and vegetables to increase the nutrients in their diet. While edible insects can also be sources of micronutrients, and most importantly, of protein, they are often overlooked because of the general negative perceptions on entomophagy (Köhler et al. 2019). Indonesia and other countries in Southeast Asia are home to around 150 to 200 edible insect species (Sirimungkararat et al. 2010).

The Papua Province is located in the easternmost part of Indonesia. The Province is divided into lowlands consisting of sago and mangrove forests, grasslands, and swamps in the coastal areas, and upland areas with primary and secondary forests, and farmed plots. Due to limited agricultural resources in the area, insects, especially grasshoppers, leaf and stick insects, cicadas and large moths and their caterpillars, remain as important protein sources in the people's daily diet. Along Papua's coastline, the most important edible insect is the Rhynchophorus bilineatus [Montrouzier, Coleoptera, Dryophthoridae], the sago beetle or palm weevil. The larvae, commonly known as "sago grubs" or "sago worms" are 
collected a month after the palm trees are cut down for sago starch production. One rotting sago palm trunk may yield as much as 500 to 600 sago grubs feeding on its starchy pith (Mercer 1994). Normally, they are consumed raw or roasted and is also considered as a local delicacy (Ramandey and van Mastrigt 2010). From informal talks in the community, it was gathered that the edible insects cost around 3 USD per $100 \mathrm{~g}$.

There are two species of sago worm in Papua, and they are differentiated by the color in their adult stage - the R. bilineatus weevil is black while $R$. ferrugineus [Olivier, Coleoptera, Dryophthoridae] is brown (Ramandey and van Mastrigt 2010; Tommaseo-Ponzetta and Paoletti 2005). R. ferrugineus is widely distributed in Asia (Indonesia, Japan, Malaysia, Papua New Guinea, the Philippines and Thailand), while the other species, R. palmarum [Linnaeus, Coleoptera, Dryophthoridae] and R. phoenicis [Fabricius, Coleoptera, Dryophthoridae] are widely distributed and used as food in the Western Hemisphere (Central America and West Indies, Mexico and South America), and in Africa (van Huis et al. 2013), respectively. Palm weevils are often considered as pests because they attack sago palms and other important palm species like the coconut, date, oil and raffia palms (van Huis et al. 2013).

Most of the species of palm weevil have already been studied. Among the various species, the following had been profiled: African palm weevil R. phoenicis in Cameroon (Fogang Mba et al. 2017; Womeni et al. 2009, 2012), Nigeria (Adeyeye 2017; Edijala et al. 2009; Ekpo and Onigbinde 2005; Elemo et al. 2011; Ogbuagu et al. 2011; Okunowo et al. 2017; Omotoso and Adedire 2007) and Ghana (Atuahene et al. 2017; Laar et al. 2017); R. palmarum in Côte d'Ivoire (Dué et al. 2009; Gbogouri et al. 2013) and Nigeria (Adeyeye 2017), and R. ferrugineus in Egypt (Abdel-Moniem et al. 2017) and Malaysia (Ali et al. 2006). However, based on the review of available scientific literature, no nutritional information can be found for the species $R$. bilineatus. In general, very little research have been conducted on the edible insects in Indonesia (Lukiwati 2010).

This study was conceptualized with the objective to give an overview of the nutritional profile of the wild sago grub Rhynchophorus bilineatus in support to the principles of dietary diversification and the alleviation of malnutrition in Indonesia and the ASEAN region. The paper discusses the protein and amino acid content as well as the fat, fatty acid, vitamin $\mathrm{E}$, and mineral content of the edible insect, the first profiling ever to be documented for the species.

\section{Materials and methods}

\section{Sago grub samples}

The grub samples $(1 \mathrm{~kg})$ were collected from the wild, specifically, from the sago palm forest in Sentani, the capital of the
Jayapura Regency in Papua, Indonesia in December 2017. The live insects were washed, patted dry, sealed in a plastic container, and frozen at $-18{ }^{\circ} \mathrm{C}$ for $24 \mathrm{~h}$ before the container was packed in a Styrofoam box together with icepacks, and transported to the Institute of Nutritional Science of the University of Hohenheim, Germany. The insects were freeze-dried (LyoQuest-85, Azbil Telstar Technologies S.L.U, Spain) for $24 \mathrm{~h}$ until constant weight was achieved, and ground for 1 min using a laboratory mill (Model A11 basic, IKA, Germany). The resulting mass was put in Falcon tubes and stored in $\mathrm{a}-80{ }^{\circ} \mathrm{C}$ freezer until further analyses could be conducted.

\section{Chemical analyses}

The protein, amino and fatty acids, as well as the mineral content of the sago grub were analyzed in duplicate at the Core Facility of the University of Hohenheim. This is an accredited testing institute (DIN EN ISO/IEC 17025:2005) with state-of-the-art equipment coupled with wellestablished laboratory protocols. On the other hand, the fat and vitamin $\mathrm{E}$ contents were measured in triplicate at the Institute of Nutritional Science, also in the University of Hohenheim using methods developed and optimized by the researchers. All the reagents used were of the highest purity and analytical grade, and purchased from either SigmaAldrich Chemie (Taufkirchen, Germany) or Merck (Darmstadt, Germany), unless stated otherwise.

Protein and amino acids The protein content was determined using the Kjeldahl method, as specified in the Official Journal of the European Union (EU), Commission Regulation (EC) No. 152/2009, Annex III C, using the nitrogen conversion factor of 6.25 (European Commission 2009). The digestion unit Kjeldatherm and distillation unit VAP 50 Carousel (Gerhardt GmbH \& Co. KG, Königswinter, Germany) were used in the analysis. The amino acids were determined following Annex III F except for tryptophan which was analyzed using the procedure in Annex III G. The amino acids were separated and measured by ion exchange chromatography and ninhydrin post-column derivatization using an amino acid analyzer (Biochrom 30, DKSH Management Ltd., Zürich, Switzerland).

The percentages and ratio of essential and non-essential amino acids (EAA and NEAA), the percentages of savory (aspartic and glutamic acids) and sweet (glycine and alanine) amino acids, the protein recovery, the amino acid score, and the most limiting amino acid, as well as whether the sago grub is a 'source' of protein or has 'high' content according to the rules in food labelling from the Codex Alimentarius (FAO/ WHO 2007) were determined based on the results of the analysis. 
The amount of protein recovered (\%) was calculated as the sum of the amino acids divided by the amount of protein in the sample multiplied by 100 . The amino acid score and the limiting amino acid were determined using the formula and suggested pattern of amino acid requirements for preschool children (2-5 years old) of FAO/WHO (1991). First, the amino acid ratios (amount in mg of an essential amino acid in $1.0 \mathrm{~g}$ of insect protein divided by the value of the same amino acid in the reference pattern) had to be calculated using the reference pattern ( $\mathrm{mg} / \mathrm{g}$ protein): histidine, 19; isoleucine, 28; leucine, 66; lysine, 58; methionine + cysteine, 25 ; phenylalanine + tyrosine, 63; threonine, 34; tryptophan, 11; and valine, 35 . The lowest amino acid ratio was then taken as the amino acid score, and the corresponding amino acid as the limiting amino acid. A food product can be labelled as a protein 'source', when its protein content is at least $10 \%$ of the nutrient reference value (NRV) or may be labelled as 'high in' protein, when the measured value is twice the amount required to be a 'source'.

Crude fat and vitamin E content The fat and vitamin E (tocopherols and tocotrienols) content were extracted and quantified following the method of Grebenstein and Frank (2012) as optimized by Irías-Mata et al. (2017). This is the first time that the method was applied to an edible insect. The oil from the sago grub was extracted using $10 \% \mathrm{n}$-hexane $(\mathrm{v} / \mathrm{v})$ and stirred for $30 \mathrm{~min}$ at room temperature. The residue was removed using vacuum filtration, and to remove the residual $\mathrm{n}$-hexane from the supernatant, a vacuum rotary evaporator (Rotavapor R-100, Büchi Labortechnik, Essen, Germany) was used at a maximum temperature of $30^{\circ} \mathrm{C}$. The extracted crude oil was transferred in a bottle wrapped in aluminum foil to prevent exposure to light, and was refrigerated at $4{ }^{\circ} \mathrm{C}$. The vitamin $\mathrm{E}$ content of the sago grub oil was analyzed using high performance liquid chromatography (HPLC) together with palm oil obtained from the same Papua region, for comparison.

The daily acceptable intakes (AI) of $5 \mathrm{mg}$ and $7.5 \mathrm{mg}$ of $\alpha$ tocopherol equivalents ( $\alpha$-TE) among children ( $1-3$ years old) and adult females (19-50 years old), respectively, were used to estimate the possible vitamin $\mathrm{E}$ contribution of the edible insect in the diet (FAO/WHO 2001). The $\alpha$-TE were calculated using the conversion factor of $1 \mathrm{mg} \alpha-\mathrm{TE}=1 \mathrm{mg} \alpha$-tocopherol, $2 \mathrm{mg} \beta$-tocopherol, $10 \mathrm{mg} \gamma$-tocopherol, $3.3 \mathrm{mg}$ $\alpha$-tocotrienol, or $20 \mathrm{mg} \beta$-tocotrienol (FAO/WHO 2016).

Fatty acids The fatty acid profile was determined according to the method developed by the Core Facility (P23-5-008). The oil from the sago grub was dissolved in diisopropyl ether and methylated by the addition of $0.2 \mathrm{M}$ trimethylsulfonium hydroxide in methanol (TMSH). The resulting solution was used for the determination of the total fatty acid pattern by capillary gas chromatography with flame ionization detection (7890A:
Capillary GC with split/splitless- and PTV-injection and FI and EC detection, Agilent Technologies, USA). The standard used was Supelco 37-Component FAME Mix (Supelco, Bellefonte, Pennsylvania, USA), and the column was an Agilent J\&W GC Column DB-23 $(30 \mathrm{~m} \times 0.25 \mathrm{~mm} \times 0.25 \mu \mathrm{m})$.

Dietary minerals and heavy metals The sago grub was first defatted using $60 \%$ petroleum ether $(v / v)$, and then digested with the ultraCLAVE III Microwave Digestor (MLS GmbH, Leutkirch im Allgäu, Germany). Approximately $300 \mathrm{mg}$ of the defatted sample was weighed out for digestion, moistened with $1 \mathrm{~mL} \mathrm{H}_{2} \mathrm{O}$ and then mixed with $2.5 \mathrm{~mL} \mathrm{HNO}_{3}$. After digestion, the resulting solution was made up to $10 \mathrm{~mL}$ with $\mathrm{H}_{2} \mathrm{O}$ and was then measured against the calibration curves of the different mineral standards using atom-emission spectrometers VistaPRO ICP-OES (Varian Inc., Palo Alto, USA) for $\mathrm{Ca}, \mathrm{Fe}, \mathrm{K}, \mathrm{Mg}, \mathrm{Mn}, \mathrm{Na}$, and $\mathrm{P}$, and ICP-MS NexION 300X (PerkinElmer, Inc., Massachusetts, USA) for $\mathrm{Cd}, \mathrm{Cu}, \mathrm{Mo}, \mathrm{Pb}$, and $\mathrm{Zn}$.

The measurements of As and Se were carried out using hydride generation atomic absorption spectrometer (AAS), and $\mathrm{Hg}$ was measured using cold vapor AAS (AAnalyst 400, PerkinElmer, Inc., Massachusetts, USA). After a prereduction step with potassium iodide and ascorbic acid, the As and Se in the digestion solution were further reacted with sodium borohydride to form arsenic hydride and selenium hydride, respectively. The hydrides were then expelled with argon from the solutions, transferred to heated quartz glass cuvettes where they decomposed to elemental As or Se, and were then measured using the AAS against their respective calibration curves. For the determination of $\mathrm{Hg}$, the freely present $\mathrm{Hg}$ in the digestion solution was reduced with sodium borohydride to elemental $\mathrm{Hg}$, and then transferred with an argon gas stream from the solution to the beam path of the AAS. The Hg concentration was then measured against a calibration curve.

From the results of the mineral analysis, the sago grub was evaluated if it can be labelled as a 'source of' $\mathrm{Ca}, \mathrm{Fe}, \mathrm{Mg}$ and $\mathrm{Zn}$ or has 'high' content according to the rules in food labelling from the Codex Alimentarius (FAO/WHO 2007). The possible contribution of these minerals (and $\mathrm{Se}$ ) to the $\mathrm{FAO} /$ WHO (2001) recommended nutrient intakes (RNI) among children (1-3 years old) and adult females (19-50 years old) were also calculated.

Data handling and analysis The results generated were first in freeze-dried (FD) basis before they were converted into wet or fresh weight (FW) basis. To convert, the results in FD basis (per $100 \mathrm{~g}$ freeze-dried sample) were divided by a conversion factor which was calculated by dividing the fresh weight of the sample by its freeze-dried weight. The moisture loss (\% of the fresh weight) due to freeze-drying was also noted. The results of the analysis are presented as mean value \pm standard 
deviation. T-test was done to compare the fatty acid composition as well as the vitamin E content of the sago grub oil with the local palm oil using GraphPad Prism 5 (GraphPad Software, San Diego, California, USA).

\section{Results}

The calculated conversion factor in order to convert FD into FW basis was 2.33 , with a moisture loss of $57 \%$. The Indonesian sago grub contained $10.39 \mathrm{~g}$ protein/100 g FW, and a $92 \%$ protein recovery. The amount of protein was slightly greater than $10 \mathrm{~g} / 100 \mathrm{~g} \mathrm{FW}$ which means that the edible insect is not only a source of the macronutrient but can be labeled as 'high in' protein based on the Codex Alimentarius (FAO/WHO 2007).

As shown in Table 1, the sago grub contained the complete set of nine essential amino acids, from tryptophan at $0.12 \mathrm{~g}$ to phenylalanine at $0.79 \mathrm{~g} / 100 \mathrm{~g} \mathrm{FW}$. Among the non-essential amino acids, glutamic acid was the most abundant at $1.27 \mathrm{~g}$, while cysteine was the least abundant at $0.08 \mathrm{~g} / 100 \mathrm{~g} \mathrm{FW}$. The total amino acid content was $9.53 \mathrm{~g} / 100 \mathrm{~g} \mathrm{FW}$, comprised of $42 \%$ essential and 58\% non-essential amino acids. The ratio between the essential to non-essential amino acids was 0.73 . Savory amino acids (aspartic and glutamic acids) were at $23 \%$, while the sweet amino acids (glycine and alanine) were at $14 \%$ of the total amino acid content. The amino acid score was 0.84 , and the limiting amino acid was methionine + cysteine (Table 2).

The sago grub contained $17.17 \mathrm{~g}$ oil $/ 100 \mathrm{~g} \mathrm{FW}$. As shown in Table 3, in $100 \mathrm{~g}$ fresh weight, there is $8.21 \mathrm{~g}$ saturated fatty acids (SFA), $8.18 \mathrm{~g}$ monounsaturated fatty acids (MUFA), and only $0.79 \mathrm{~g}$ polyunsaturated fatty acids (PUFA). In $0.5 \mathrm{~g}$ sago grub oil, palmitic acid has the highest concentration (42\%) among the SFA, while oleic acid (45\%) is highest among the MUFA, and linoleic acid (3\%) among the PUFA. The same pattern was observed in the palm oil sample, although it contained $0.09 \%$ margaric acid and $0.23 \%$ eicosenoic acid, two fatty acids not detected in the sago grub oil.
Table 2 Essential amino acid ratios based on the FAO/WHO pattern for children ( $2-5$ years old), amino acid score and limiting amino acid of the sago grub

\begin{tabular}{lll}
\hline $\begin{array}{l}\text { Essential amino } \\
\text { acid (AA) }\end{array}$ & $\begin{array}{l}\text { FAO/WHO pattern for } \\
\text { children (2-5 years old) }\end{array}$ & Ratio \\
\hline Histidine & 19 & 1.13 \\
Isoleucine & 28 & 1.37 \\
Leucine & 66 & 1.04 \\
Lysine & 58 & 1.08 \\
Methionine + Cysteine & 25 & 0.84 \\
Phenylalanine + Tyrosine & 63 & 1.75 \\
Threonine & 34 & 1.24 \\
Tryptophan & 11 & 1.05 \\
Valine & 35 & 1.49 \\
AA Score & & 0.84 \\
Limiting AA & & Met + Cys \\
\hline
\end{tabular}

The vitamin E profile of the sago grub is shown in Table 4. Except for $\delta$ - and $\beta$-tocopherol, the sago grub oil contained significantly less tocopherols and tocotrienols compared to palm oil. The oil from the sago grub had the most $\alpha$ tocopherol $(43.25 \mu \mathrm{g} / \mathrm{g}$ oil $)$ and the least amount of $\delta$ tocopherol $(0.12 \mu \mathrm{g} / \mathrm{g}$ oil $)$ among the vitamin E congeners. $\delta$-Tocopherol was not detected in the palm oil at all.

The sago grub contained essential minerals that ranged from $<0.002$ to $204.55 \mathrm{mg} / 100 \mathrm{~g} \mathrm{FW}$ (Table 5). At the same time containing heavy metals - $\mathrm{As}, \mathrm{Cd}, \mathrm{Pb}$ and $\mathrm{Hg}$ - that ranged from $<0.002 \mathrm{mg}$ to $0.013 \mathrm{mg} / 100 \mathrm{~g} \mathrm{FW}$ (Table 6).

Table 7 shows the sago grub's micronutrient contribution as a percentage of the AI or the RNI specified by FAO/WHO (2001) for children (1-3 years old) and adult females (1950 years old). The sago grub can cover $10-16 \%$ of the acceptable intakes of $\alpha$-tocopherol equivalents ( $\alpha$-TE), less than $12 \%$ of the RNI for selenium; less than $6 \%$ for iron; and less than $3 \%$ for calcium. On the other end of the spectrum, the sago grub can provide a good amount of magnesium (24-
Table 1 Essential and nonessential amino acid content (mean values in $\mathrm{g} / 100 \mathrm{~g} \mathrm{FW} \pm$ $\mathrm{SD} ; n=2)$ of sago grub

\begin{tabular}{llll}
\hline Essential amino acid & $\mathrm{g} / 100 \mathrm{~g} \mathrm{FW}$ & Non-essential amino acid & $\mathrm{g} / 100 \mathrm{~g} \mathrm{FW}$ \\
\hline Histidine & $0.22 \pm 0.00$ & Alanine & $0.80 \pm 0.00$ \\
Isoleucine & $0.40 \pm 0.00$ & Aspartic acid & $0.88 \pm 0.00$ \\
Leucine & $0.71 \pm 0.00$ & Arginine & $0.46 \pm 0.00$ \\
Lysine & $0.65 \pm 0.00$ & Cysteine & $0.08 \pm 0.00$ \\
Methionine & $0.14 \pm 0.00$ & Glutamic acid & $1.27 \pm 0.01$ \\
Phenylalanine & $0.79 \pm 0.00$ & Glycine & $0.53 \pm 0.00$ \\
Threonine & $0.44 \pm 0.00$ & Proline & $0.59 \pm 0.00$ \\
Tryptophan & $0.12 \pm 0.00$ & Serine & $0.55 \pm 0.00$ \\
Valine & $0.54 \pm 0.01$ & Tyrosine & $0.36 \pm 0.00$ \\
Sum & $4.01 \pm 0.00$ & Sum & $5.52 \pm 0.00$ \\
\hline
\end{tabular}


Table 3 Fatty acid profiles (mean values $\pm \mathrm{SD} ; n=2)$ of the Indonesian sago grub and palm oil

\begin{tabular}{lllll}
\hline Fatty acid (FA) & & \multicolumn{2}{l}{ \% FA in 0.5 g Oil } & \multirow{2}{*}{ Sago grub (g FA/100 g FW) } \\
\cline { 3 - 4 } & & Palm & Sago grub & \\
\hline C12:0*** & Lauric & $0.130 \pm 0.000$ & $0.030 \pm 0.000$ & $0.005 \pm 0.000$ \\
C14:0*** & Myristic & $0.805 \pm 0.007$ & $1.075 \pm 0.007$ & $0.185 \pm 0.001$ \\
C15:0* & Pentadecanoic & $0.045 \pm 0.007$ & $0.085 \pm 0.007$ & $0.015 \pm 0.001$ \\
C16:0** & Palmitic & $34.740 \pm 0.735$ & $42.455 \pm 0.035$ & $7.290 \pm 0.006$ \\
C17:0 & Margaric & $0.090 \pm 0.014$ & ND & ND \\
C18:0 & Stearic & $3.940 \pm 0.438$ & $3.670 \pm 0.014$ & $0.630 \pm 0.002$ \\
C20:0 & Arachidic & $0.370 \pm 0.099$ & $0.470 \pm 0.014$ & $0.081 \pm 0.002$ \\
C22:0 & Behenic & $0.090 \pm 0.014$ & ND & ND \\
Total SFA*** & & $40.210 \pm 0.127$ & $47.785 \pm 0.035$ & $8.205 \pm 0.006$ \\
C16:1*** & Palmitoleic & $0.195 \pm 0.035$ & $3.015 \pm 0.007$ & $0.518 \pm 0.001$ \\
C18:1n9c* & Oleic & $46.810 \pm 0.410$ & $44.630 \pm 0.141$ & $7.663 \pm 0.024$ \\
C20:1 & Eicosenoic & $0.225 \pm 0.007$ & ND & ND \\
Total MUFA ${ }^{\text {ns }}$ & & $47.220 \pm 0.354$ & $47.645 \pm 0.148$ & $8.181 \pm 0.025$ \\
C18:2n6c** & Linoleic & $12.380 \pm 0.438$ & $3.010 \pm 0.212$ & $0.517 \pm 0.036$ \\
C18:3n3c*** & $\alpha-l i n o l e n i c$ & $0.215 \pm 0.021$ & $1.560 \pm 0.028$ & $0.268 \pm 0.005$ \\
Total PUFA** & & $12.595 \pm 0.460$ & $4.570 \pm 0.184$ & $0.785 \pm 0.032$ \\
\hline
\end{tabular}

Legend: $p<0.001$, extremely significant $* * * ; p=0.001$ to 0.01 , very significant $* * ; p=0.01$ to 0.05 , significant $*$; $p>0.05, n s$ not significant; ND Not detected; SFA Saturated fatty acids; MUFA Monounsaturated fatty acids; PUFA Polyunsaturated fatty acids
$88 \%)$ and zinc (29-34\%) in the daily RNI of children and adult females if it is included in their diet .

\section{Discussion}

According to Payne et al. (2016), the palm weevil larva, in general, is significantly more healthful than beef and chicken based on its nutrient value score calculated from publicly

Table 4 Vitamin E profiles (mean values in $\mu \mathrm{g} / \mathrm{g} \pm \mathrm{SD} ; n=3$ ) of the Indonesian sago grub and palm oil

\begin{tabular}{lll}
\hline Vitamin E $(\mu \mathrm{g} / \mathrm{g}$ Oil $)$ & Sago grub & Palm \\
\hline$\alpha$-Tocotrienol*** & $0.80 \pm 0.06$ & $92.58 \pm 8.16$ \\
$\beta$-Tocotrienol*** & $0.18 \pm 0.09$ & $2.30 \pm 0.33$ \\
$\delta$-Tocotrienol*** & $0.47 \pm 0.08$ & $23.50 \pm 3.29$ \\
$\gamma$-Tocotrienol*** & $2.52 \pm 0.12$ & $79.45 \pm 8.52$ \\
$\alpha$-Tocopherol** & $43.25 \pm 2.69$ & $87.47 \pm 8.96$ \\
$\beta$-Tocopherol*** & $3.85 \pm 0.15$ & $0.19 \pm 0.05$ \\
$\delta$-Tocopherol & $0.12 \pm 0.01$ & $\mathrm{ND}$ \\
$\gamma$-Tocopherol & $0.26 \pm 0.05$ & $0.49 \pm 0.12$ \\
Total T** & $47.48 \pm 2.67$ & $88.14 \pm 9.10$ \\
Total T3*** & $3.97 \pm 0.29$ & $197.82 \pm 7.12$ \\
Total VE*** & $51.44 \pm 2.45$ & $285.97 \pm 15.01$ \\
\hline
\end{tabular}

Legend: $p<0.001$, extremely significant $* * * ; p=0.001$ to 0.01 , very significant $* * ; p=0.01$ to 0.05 , significant $* ; N D$ Not detected; $T$ Tocopherol; T3 Tocotrienol; VE Vitamin E available nutrient composition data. The sago grub Rhynchophorus bilineatus in this study has a slightly higher protein content (10.39 g protein/100 g FW) than the Rhynchophorus ferrugineus larva from the Southeast Sulawesi Province also in Indonesia. According to Nirmala et al. (2017), the latter contained $9.70 \mathrm{~g}$ protein $/ 100 \mathrm{~g} \mathrm{FW}$. On the other hand, the sago grub has a lower protein and fat content (17.17 g oil/100 g FW) compared to the results of Abdel-Moniem et al. (2017) on their analysis of the pupae and larvae of red palm weevil, Rhynchophorus ferrugineus Olivier in Egypt. The Egyptian insect had a higher protein content $(32 \%)$ in the pupal stage than in the larval stage

Table 5 Mineral content (mean values in $\mathrm{mg} / 100 \mathrm{~g} \mathrm{FW} \pm \mathrm{SD} ; n=2$ ) of the sago grub and the limits for food labelling 'source of' and 'high in'

\begin{tabular}{llll}
\hline Dietary mineral $(\mathrm{mg} / 100 \mathrm{~g} \mathrm{FW})$ & 'Source of' & 'High in' \\
\hline Calcium & $14.93 \pm 1.00$ & 120 & 240 \\
Copper & $0.38 \pm 0.03$ & & \\
Iron & $0.77 \pm 0.04$ & 2.1 & 4.2 \\
Magnesium & $52.64 \pm 2.56$ & 45 & 90 \\
Manganese & $0.35 \pm 0.02$ & & \\
Molybdenum & $0.003 \pm 0.000$ & & \\
Phosphorus & $102.32 \pm 4.38$ & & \\
Potassium & $204.55 \pm 4.77$ & & \\
Selenium & $<0.002 \pm 0.000$ & & 4.5 \\
Sodium & $16.59 \pm 0.40$ & & \\
Zinc & $2.87 \pm 0.15$ & 2.25 & \\
\hline
\end{tabular}


Table 6 Heavy metal content (mean values in $\mathrm{mg} / 100 \mathrm{~g} \mathrm{FW} \pm$ $\mathrm{SD} ; n=2$ ) of the sago grub with the limits for feed material and complete feed

\begin{tabular}{llll}
\hline Heavy metal $(\mathrm{mg} / 100 \mathrm{~g} \mathrm{FW})$ & $\begin{array}{l}\text { Feed material max. limit } \\
(\mathrm{mg} / 100 \mathrm{~g} \mathrm{FW})\end{array}$ & $\begin{array}{l}\text { Complete feed max. limit } \\
(\mathrm{mg} / 100 \mathrm{~g} \mathrm{FW})\end{array}$ \\
\hline Arsenic & $<0.002 \pm 0.000$ & 0.176 & 0.176 \\
Cadmium & $0.013 \pm 0.000$ & 0.176 & 0.044 \\
Lead & $<0.004 \pm 0.000$ & 0.880 & 0.440 \\
Mercury & $<0.002 \pm 0.000$ & 0.009 & 0.009 \\
\hline
\end{tabular}

(30\%). Meanwhile, the fat content of the larvae was $22 \%$ while that of the pupae was $19 \%$. Other palm weevil larvae like those of Rhynchophorus palmarum and Rhynchophorus phoenicis have protein contents ranging from 7 to $21 \mathrm{~g} / 100 \mathrm{~g}$ FW (FAO 2017), and fat contents ranging from 6.24-7.48 g/ $100 \mathrm{~g} \mathrm{FW}$ (Adeyeye 2017). On the other hand, the Rhynchophorus phoenicis larvae from Cameroon have protein and fat contents of $8 \mathrm{~g} / 100 \mathrm{~g}$ and $21 \mathrm{~g} / 100 \mathrm{~g} \mathrm{FW}$, respectively (Fogang Mba et al. 2017) while Rhynchophorus phoenicis larvae from Nigeria contained $24 \mathrm{~g}$ protein/100 g FW, and $15 \mathrm{~g}$ fat/100 FW (Okunowo et al. 2017). The variability in the protein and fat content or the proximate composition of the larvae, in general, could be directly attributed to the difference in measurement methods, and in the diet of the insects. Indirectly, it could also be due to the difference in body size, age during harvest, and the living environment at the geographical origin or source of the edible insects under study (Raheem et al. 2019; van Huis and Oonincx 2017). Information on the effect of these factors on the nutrient profile of edible insects is vital, as any one of them could be the deciding factor in the effective domestication and industrial production of these insects (Raheem et al. 2019).

It is predicted that the world population will grow over nine billion by 2050 , and one of the biggest challenges is to increase the global food supply by at least $1.30 \%$ per year (Fischer et al. 2014; Godfray 2015; Grafton et al. 2015). Attaining food security in the future would necessitate the utilization of sustainable alternative protein and fat sources like the Indonesian sago grub, which, as a component of a diversified diet, could also contribute in attaining the Sustainable Development Goal (SDG) to end all forms of malnutrition, especially protein energy malnutrition (PEM), by 2030. PEM occurs in both developed and developing countries, and is a leading cause of death in young children all over the world (Grover and Ee 2009).

The sago grub has a high protein recovery $(92 \%)$, this means that the edible insect can provide the protein in the diet of the people in the Papua Province, especially those who use sago starch, with its low protein content, as staple food. The high protein recovery can also be translated as the protein content which is mainly contributed by the amino acids, and so, only $8 \%$ of the protein may be attributed to chitin and other nitrogen-containing compounds (Finke 2015). Chitin is present in the exoskeleton of edible insects, and it could trigger an allergic reaction in some people who possess very small amount of bacterial chitinolytic enzyme in their gut (Dušková et al. 2011; EFSA 2015). On the other hand, chitin and chitosan (its most studied derivative) have also been
Table 7 Contribution (\%) of the micronutrients in the sago grub to the daily acceptable and recommended nutrient intakes set by FAO/WHO (2001)

\begin{tabular}{|c|c|c|c|c|c|}
\hline \multirow{2}{*}{$\begin{array}{l}\text { Micronutrient } \\
\text { Vitamin }\end{array}$} & \multirow[t]{2}{*}{ Amount (mg/100 g FW) } & \multicolumn{2}{|c|}{ Children (1-3 years old) } & \multicolumn{2}{|c|}{$\begin{array}{l}\text { Adult Females (19- } \\
50 \text { years old, pre- } \\
\text { menopausal) }\end{array}$} \\
\hline & & AI (mg/day) & $\% \mathrm{AI}$ & AI (mg/day) & $\% \mathrm{AI}$ \\
\hline $\begin{array}{l}\alpha \text {-Tocopherol } \\
\beta \text {-Tocopherol }\end{array}$ & $\begin{array}{l}0.743 \pm 0.046 \\
0.066 \pm 0.003\end{array}$ & & 15.60 & 7.5 & 10.40 \\
\hline$\gamma$-Tocopherol & $0.004 \pm 0.001$ & & & & \\
\hline$\alpha$-Tocotrienol & $0.014 \pm 0.001$ & & & & \\
\hline$\beta$-Tocotrienol & $0.003 \pm 0.001$ & & & & \\
\hline$\alpha-\mathrm{TE}$ & $0.780 \pm 0.046$ & 5 & & & \\
\hline Mineral & & RNI (mg/day) & $\% \mathrm{RNI}$ & RNI (mg/day) & $\% \mathrm{RNI}$ \\
\hline Calcium & $14.93 \pm 1.00$ & 500 & 2.99 & 1000 & 1.49 \\
\hline Iron ( $5 \%$ bioavailability) & $0.77 \pm 0.04$ & 12 & 6.42 & 59 & 1.31 \\
\hline Magnesium & $52.64 \pm 2.56$ & 60 & 87.73 & 220 & 23.93 \\
\hline Selenium & $<0.002 \pm 0.000$ & 0.017 & $<11.76$ & 0.026 & $<7.69$ \\
\hline Zinc (low bioavailability) & $2.87 \pm 0.15$ & 8.4 & 34.17 & 9.8 & 29.29 \\
\hline
\end{tabular}

Legend: $\alpha$-TE $\alpha$-Tocopherol equivalents; AI Acceptable intakes; RNI Recommended nutrient intake 
linked to adaptive immunity (Komi et al. 2018). Nagatani et al. (2012) have reported the positive effect of chitin in the control of inflammation of the intestines; Bae et al. (2013) have reported that chitin and chitosan are capable of suppressing anaphylaxis symptoms from peanut allergy; and Wiesner et al. (2015) have reported the involvement of chitin in the immunity against pulmonary cryptococcal infection.

The sago grub met the FAO/WHO (1973) requirements of $40 \%$ essential amino acids and a 0.60 ratio between essential to non-essential amino acids. In a study on mice by Romano et al. (2019), it was concluded that the ratio among EAA and NEAA is the most probable factor responsible for the healthpromoting effects of proteins, and that the higher the ratio (closer to 1 or even greater than 1 if supplemented with additional EAA) in the diet, the more efficient it is to increase the lifespan of people suffering from malnutrition.

Cereals like rice and maize, staple foods in various regions around the world, are mostly low in lysine and may lack tryptophan and threonine. However, these amino acids are abundantly present in some insect species (Bukkens 2005). In the case of the Indonesian sago grub, lysine is the third most abundant essential amino acid after phenylalanine and leucine. It also contains threonine and tryptophan, although they are the least abundant among both essential and non-essential amino acids.

When compared to the $\mathrm{FAO} / \mathrm{WHO}$ requirement for preschool children aged 2-5 years, the limiting amino acid in the sago grub is the sulfur amino acid - methionine + cysteine. In a study by Finke (2015), when compared to the national requirements for rats or poultry, the limiting amino acid of crickets, mealworms, superworms, and waxworms is also methionine and cystine. In contrast, the limiting amino acid of the larva of the African palm weevil, Rhynchophorus phoenicis, from Nigeria was tryptophan (Elemo et al. 2011).

Palmitic (42\%), oleic (45\%), and linoleic (3\%) acids are the major fatty acids in the sago grub oil which were similarly observed by Ekpo and Onigbinde (2005) on Rhynchophorus phoenicis, with the larva oil containing palmitic (32\%), oleic (40\%) and linoleic (13\%) acids. Generally, insects have more unsaturated fatty acids (UFA) compared to saturated fatty acids (SFA) (de Castro et al. 2018). The sago grub has a higher SFA (48\%) and MUFA (48\%), but a lower PUFA (5\%) content compared to the larvae of Rhynchophorus phoenicis and Rhynchophorus palmarum from Nigeria with SFA ranging from 29 to $31 \%$, MUFA from 37 to $40 \%$, and PUFA from 29 to $34 \%$. The PUFA/SFA ratio ranged from 0.92 to 1.20 (Adeyeye 2017), while the PUFA/SFA ratio of the Indonesian sago grub is only 0.096. Nevertheless, the high amount of unsaturated fatty acids (MUFA + PUFA) has kept the sago grub oil, like other plant oils, liquid even at a low storage temperature $\left(4^{\circ} \mathrm{C}\right)$. The oil extracted from the sago grub can not only be used in food and animal feed, it could also have possible industrial applications (e.g. cosmetics, lubrication, pharmaceutical industries).
Like vitamins $\mathrm{A}, \mathrm{D}$, and $\mathrm{K}$, vitamin $\mathrm{E}$ is a fat-soluble vitamin. It is composed of fat-soluble compounds - four of which has the chromanol ring structure bound to a saturated 15carbon side chain (tocopherols), and another four with three trans double bonds in the carbon side-chain (tocotrienols). In the identification of the compounds, Greek prefixes $(\alpha, \beta, \gamma$, $\delta$ ) are used to denote the number and position of the methyl groups substituted at the chromanol ring (Frank et al. 2012). Vitamin E is exclusively produced by photosynthetic organisms and, thus, present in plant-based foods, particularly in vegetable oils (Sen et al. 2006). On the other hand, animals can acquire their vitamin $\mathrm{E}$ content from the plants that they consume or by eating other animals that consumed the vitamin E-containing plants, and had stored the micronutrient in their liver, muscles and fat. It is therefore understandable that the palm oil sample yielded a significantly higher vitamin E content compared to the oil from the sago grub. A gram of palm oil contained $305 \mu \mathrm{g}$ vitamin E, $71 \%$ of which is composed of tocotrienols, while a gram of sago grub oil only contained $51 \mu \mathrm{g}$ vitamin E, $92 \%$ of which is composed of tocopherols. $\alpha$-tocotrienol was the predominant vitamin E compound in the palm oil while $\alpha$-tocopherol was the predominant compound in the sago grub oil.

The palm oil did not contain a detectable amount of $\delta$ tocopherol, similar to the oils obtained from Costa Rican palms via screw press extraction (Irías-Mata et al. 2017). While in contrast, the sago grub oil contained $\delta$-tocopherol $(0.12 \mu \mathrm{g} / \mathrm{g}$ oil $)$, and a significantly high amount of $\beta$ tocopherol (3.85 $\mu \mathrm{g} / \mathrm{g}$ oil). The sago grub could have only obtained their vitamin $\mathrm{E}$ from the starchy palm pith that they consume.

The $\alpha$-TE in 100 g sago grub can provide children with $16 \%$ of their daily AI level, and can cover $10 \%$ of adult females' daily AI. Both tocopherols $(\alpha, \beta, \gamma)$ and tocotrienols $(\alpha, \beta)$ contribute in the calculation of the $\alpha$-TE. Although $\gamma$ tocopherol is the predominant class of dietary vitamin $\mathrm{E}, \alpha$ tocopherol is the most significant vitamin $\mathrm{E}$ form for human nutrition and physiology (Rigotti 2007; WHO/FAO 2004). On the other hand, the tocotrienols, aside from being powerful antioxidants, are known to possess great neuroprotective, anti-cancer and cholesterol-lowering properties (Sen et al. 2006).

According to the WHO, every $100 \mathrm{~g}$ of weevil larvae contains $4.3 \mathrm{mg}$ iron, $461 \mathrm{mg}$ calcium, and other vitamins and minerals (Mercer 1997). In the sago grub, Rhynchophorus bilineatus, potassium (204.55 mg/100 g FW), phosphorus (102. $32 \mathrm{mg} / 100 \mathrm{~g} \mathrm{FW})$, and magnesium $(52.64 \mathrm{mg} / 100 \mathrm{~g}$ FW) were the most abundant minerals, while selenium $(<$ $0.002 \mathrm{mg} / 100 \mathrm{~g} \mathrm{FE})$ and molybdenum $(0.003 \mathrm{mg} / 100 \mathrm{~g}$ FW) were the least abundant. Based on the Codex Alimentarius (FAO/WHO 2007), the sago grub is not a source of iron and calcium. This is as expected since invertebrates without a mineralized skeleton can contain very little calcium 
(de Castro et al. 2018). On the other hand, the sago grub can be labelled as a source of zinc and magnesium. There is, however, a gap in information regardingthe bioavailability of these minerals (de Castro et al. 2018).

Zinc is an integral component of more than 300 enzymes taking part in the synthesis and metabolism of both macro and micronutrients. It also helps maintain cell and organ integrity and immunity and plays a significant role in gene expression. Likewise, magnesium is a co-factor of various enzymes that are engaged in the metabolism of energy, synthesis of protein and nucleic acids (DNA and RNA), and the regulation of the electrostatic potential of neural tissues and cellular membranes. It is also involved in the regulation of potassium and the utilization of calcium in the body (FAO/WHO 2001). The sago grub (100 g FW) can provide children (1-3 years old) with $34 \%$ and $88 \%$ of their daily RNI for zinc and magnesium, respectively, while it can provide adult females (19-50 years old) with $29 \%$ and $24 \%$ of their daily RNI for the same minerals. However, integrating the sago grub in the diet is not so easy. Aside from the sensory aspect, there are several other issues concerning entomophagy.

One of these concerns is the possibility that the edible insects are contaminated with pesticides and heavy metals from the environment they dwell in. Because of their highly toxic nature, arsenic, cadmium, lead and mercury are considered extremely dangerous to human health. However, since the standards on heavy metals in edible insects for human consumption are not yet available, the measured values in this study were compared with the maximum allowable levels (converted to $\mathrm{mg} / 100 \mathrm{~g}$ fresh weight basis) for feed material and complete feed set in the Official Journal of the European Union, Commission Regulation (EU) No. 1275/2013 for arsenic, cadmium and lead (European Commission 2013), and in the Directive 2002/32/EC of the European Parliament and of the Council of 7 May 2002 on undesirable substances in animal feed for mercury (European Parliament and Council 2002). From the results, the sago grub showed less than the maximum limits for arsenic, cadmium, lead and mercury for feed material and complete feed. The grub samples were collected from the wild, and these results can also be a confirmation that the environment where they come from is relatively safe and free of harmful pesticides and heavy metals.

\section{Conclusion}

The $R$. bilineatus is an indigenous natural product of the Papua Province in Indonesia. Based on the results of this study, it contains micronutrients (tocopherols, tocotrienols, and minerals), and can be an alternative source of fatty acids and oil, and amino acids and protein. Its propagation and utilization should be encouraged especially in areas in Indonesia, and maybe in neighboring countries where they are endemic, and where malnutrition is also prevalent. The consumption of edible insects should be considered as a component of dietary diversification - a sustainable way of alleviating the nutritional status of the population.

Acknowledgments As a part of the doctoral thesis of R.K., this article was written under the Dr. Hermann Eiselen PhD Grant of the Foundation Fiat Panis, and the Food Security Center - Excellence Scholarship of the German Academic Exchange Service (DAAD) with the funds of the Federal Ministry of Economic Cooperation and Development (BMZ), Germany.

The authors would also like to thank Mr. Maxianus Lamanepa for his role in collecting and preparing the samples for transport from Indonesia to Germany, and Prof. Jan Frank for allowing R.K. and A.I. to carry out the fat and vitamin $\mathrm{E}$ analyses in the laboratory of Food Biofunctionality of the Institute of Nutritional Science, University of Hohenheim, Stuttgart, Germany.

Funding Information Open Access funding provided by Projekt DEAL.

\section{Compliance with ethical standards}

Conflict of interest The authors declare that they have no conflict of interest.

Open Access This article is licensed under a Creative Commons Attribution 4.0 International License, which permits use, sharing, adaptation, distribution and reproduction in any medium or format, as long as you give appropriate credit to the original author(s) and the source, provide a link to the Creative Commons licence, and indicate if changes were made. The images or other third party material in this article are included in the article's Creative Commons licence, unless indicated otherwise in a credit line to the material. If material is not included in the article's Creative Commons licence and your intended use is not permitted by statutory regulation or exceeds the permitted use, you will need to obtain permission directly from the copyright holder. To view a copy of this licence, visit http://creativecommons.org/licenses/by/4.0/.

\section{References}

Abdel-Moniem ASH, El-Kholy MY, Elshekh WEA (2017) The red palm weevil, Rhynchophorus ferrugineus Olivier, as edible insects for food and feed a case study in Egypt. Res J Pharm Biol Chem Sci $8: 1653-1658$

Adeyeye EI (2017) Studies on the lipid composition of two types of African palm grubs consumed in Nigeria. EC Nutrition 7(3):124 138

Ali OM, Chu KL, Wang CW (2006) Neutral lipid profile of sago worm, the larva of weevil Rhynchophorus ferrugineus. In: Proceedings of the 1 st international conference on natural resources engineering and technology, pp 233-236

Atuahene CC, Adjei MB, Adu MA, Quaye B, Opare MB, Benney R (2017) Evaluating the potential of edible insects (palm weevil Rhynchophorus phoenicis larvae) as an alternative protein source for humans. J Anim Sci Adv 7:1897-1901. https://doi.org/10. 5455/jasa.19700101120000

Bae M-J, Shin HS, Kim E-K, Kim J, Shon D-H (2013) Oral administration of chitin and chitosan prevents peanut-induced anaphylaxis in a murine food allergy model. Int J Biol Macromol 61:164-168. https://doi.org/10.1016/j.ijbiomac.2013.06.017 
Bukkens SGF (2005) Insects in the human diet: nutritional aspects. In: Paoletti MG (ed) Ecological implications of minilivestock: role of rodents, frogs, snails and insects for sustainable development. Science Publishers, New Hampshire, pp 545-577

de Castro RJS, Ohara A, Aguilar JGS, MAF D (2018) Nutritional, functional and biological properties of insect proteins: processes for obtaining, consumption and future challenges. Trends Food Sci Technol 76:82-89. https://doi.org/10.1016/j.tifs.2018.04.006

Dué EA, Zabri HCBL, Kouadio JPEN, Kouamé LP (2009) Fatty acid composition and properties of skin and digestive fat content oils from Rhynchophorus palmarum L. larva. Afr J Biochem Res 3: 89-94

Dušková J, Tishchenko G, Ponomareva E, Šimůnek J, Koppová I, Skálová T, Štěpánková A, Hašek J, Dohnálek J (2011) Chitinolytic enzymes from bacterium inhabiting human gastrointestinal tract critical parameters of protein isolation from anaerobic culture. Acta Biochim Pol 58:261-263

Edijala JK, Egbogbo O, Anigboro AA (2009) Proximate composition and cholesterol concentrations of Rhynchophorus phoenicis and Oryctes monoceros larvae subjected to different heat treatments. Afr J Biotechnol 8:2346-2348

EFSA (2015) Risk profile related to production and consumption of insects as food and feed. 13:4257. https://doi.org/10.2903/j.efsa.2015. 4257

Ekpo KE, Onigbinde AO (2005) Nutritional potentials of the larva Rhynchophorus phoenicis (F). Pak J Nutr 4:287-290

Elemo BO, Elemo GN, Makinde MA, Erukainure OL (2011) Chemical evaluation of African palm weevil, Rhychophorus phoenicis, larvae as a food source. J Insect Sci 11:1-6

European Commission (2009) Commission regulation (EC) no. 152/2009 of 27 January 2009 laying down the methods of sampling and analysis for the official control of feed. https://eur-lex.europa.eu/ LexUriServ/LexUriServ.do?uri=OJ:L:2009:054:0001:0130:EN: PDF

European Commission (2013) Commission regulation (EU) no. 1275/ 2013 of 6 December 2013 amending annex I to directive 2002/32/ EC of the European parliament and of the council as maximum levels for arsenic, cadmium, lead, nitrites, volatile mustard oil and harmful botanical impurities

European Parliament and Council (2002) Directive 2002/32/EC of the European parliament and of the council of 7 May 2002 on undesirable substances in animal feed

FAO (2017) FAO/INFOODS food composition database for biodiversity version 4.0 - BioFoodComp4.0. http://www.fao.org/infoods/ infoods/tables-and-databases/faoinfoods-databases/en/. Accessed 23 July 2018

FAO/WHO (1973) Energy and protein requirements: Report of a Joint FAO/WHO ad hoc expert committee, Rome, 22 March-2 April 1971. Technical report series / World Health Organization, vol 522, Geneva, Switzerland

FAO/WHO (1991) Protein quality evaluation: report of joint FAO/WHO expert consultation. FAO Food and Nutrition Paper

FAO/WHO (2001) Human vitamin and mineral requirements: report of a joint FAO/WHO expert consultation Bangkok, Thailand, Rome, Italy

FAO/WHO (2007) Food labelling, Rome, Italy. http://www.fao.org/ documents/card/en/c/5eb2d33b-d2ad-505e-898a-6aeba60ec896/. Accessed 11 Mar 2018

FAO/WHO (2016) Draft NRV-R for vitamin E, Hamburg, Germany

Finke MD (2015) Complete nutrient content of four species of commercially available feeder insects fed enhanced diets during growth. Zoo Biol 34:554-564. https://doi.org/10.1002/zoo.21246

Fischer T, Byerlee D, Edmeades GO (2014) Copy yields and global food security: will yield increase continue to feed the world? / Tony Fischer, Derek Byerlee, Greg Edmeades. ACIAR monograph series, 1031-8194, no. 158. ACIAR, Canberra, ACT
Fogang Mba AR, Kansci G, Viau M, Hafnaoui N, Meynier A, Demmano G, Genot C (2017) Lipid and amino acid profiles support the potential of Rhynchophorus phoenicis larvae for human nutrition. J Food Compos Anal 60:64-73. https://doi.org/10.1016/j.jfca.2017.03.016

Frank J, Chin XWD, Schrader C, Eckert GP, Rimbach G (2012) Do tocotrienols have potential as neuroprotective dietary factors? Ageing Res Rev 11:163-180. https://doi.org/10.1016/j.arr.2011.06. 006

Gbogouri GA, Beugre GAM, Brou K, Atchibri OA, Linder M (2013) Rhynchophorus palmarum L. larva, an edible insect in Côte D'Ivoire: nutritional value and characterization of the lipid fraction. Int J Chem Sci 11:1692-1704

Godfray HCJ (2015) The debate over sustainable intensification. Food Sec 7:199-208. https://doi.org/10.1007/s12571-015-0424-2

Grafton RQ, Daugbjerg C, Qureshi ME (2015) Towards food security by 2050. Food Sec 7:179-183. https://doi.org/10.1007/s12571-0150445-x

Grebenstein N, Frank J (2012) Rapid baseline-separation of all eight tocopherols and tocotrienols by reversed-phase liquid-chromatography with a solid-core pentafluorophenyl column and their sensitive quantification in plasma and liver. J Chromatogr A 1243:39-46. https://doi.org/10.1016/j.chroma.2012.04.042

Grover Z, Ee LC (2009) Protein energy malnutrition. Pediatr Clin N Am 56:1055-1068. https://doi.org/10.1016/j.pcl.2009.07.001

Irías-Mata A, Stuetz W, Sus N, Hammann S, Gralla K, Cordero-Solano A, Vetter W, Frank J (2017) Tocopherols, tocomonoenols, and tocotrienols in oils of Costa Rican palm fruits: a comparison between six varieties and chemical versus mechanical extraction. J Agric Food Chem 65:7476-7482. https://doi.org/10.1021/acs.jafc. $7 \mathrm{~b} 02230$

Köhler R, Kariuki L, Lambert C, Biesalski HK (2019) Protein, amino acid and mineral composition of some edible insects from Thailand. J Asia Pac Entomol 22:372-378. https://doi.org/10.1016/j.aspen. 2019.02.002

Komi DEA, Sharma L, Dela Cruz CS (2018) Chitin and its effects on inflammatory and immune responses. Clin Rev Allergy Immunol 54:213-223. https://doi.org/10.1007/s12016-017-8600-0

Laar A, Kotoh A, Parker M, Milani P, Tawiah C, Soor S, Anankware JP, Kalra N, Manu G, Tandoh A, Zobrist S, Engmann C, Pelto G (2017) An exploration of edible palm weevil larvae (Akokono) as a source of nutrition and livelihood: perspectives from Ghanaian stakeholders. Food Nutr Bull 38:455-467. https://doi.org/10.1177/ 0379572117723396

Lukiwati DR (2010) Teak caterpillars and other edible insects in Java. In: Durst PB, Johnson DV, Leslie RN, Shono K (eds) Forest insects as food: humans bite back: proceedings of a workshop on Asia-Pacific resources and their potential for development, 19-21 February 2008, Chiang Mai, Thailand. FAO Regional Office for Asia and the Pacific, Bangkok, Thailand, pp 99-104

Mercer CWL (1994) Sago grub production in Labu swamp near Lae Papua New Guinea. Klinkii 5:30-34

Mercer CWL (1997) Sustainable production of insects for food and income by New Guinea villagers. Ecol Food Nutr 36:151-157. https:// doi.org/10.1080/03670244.1997.9991512

Nagatani K, Wang S, Llado V, Lau CW, Li Z, Mizoguchi A, Nagler CR, Shibata Y, Reinecker H-C, Mora JR, Mizoguchi E (2012) Chitin microparticles for the control of intestinal inflammation. Inflamm Bowel Dis 18:1698-1710. https://doi.org/10.1002/ibd.22874

Nirmala IR, Trees S, Pramono MS (2017) Sago worms as a nutritious traditional and alternative food for rural children in Southeast Sulawesi, Indonesia. Asia Pac J Clin Nutr 26:S40-S49. https://doi. org/10.6133/apjen.062017.s4

Ogbuagu MN, Ohondu I, Nwigwe C (2011) Fatty acid and amino acid profiles of the larva of raffia palm weevil: Rhynchophorus phoenicis. Pac J Sci Technol 12:392-400 
Okunowo WO, Olagboye AM, Afolabi LO, Oyedeji AO (2017) Nutritional value of Rhynchophorus phoenicis (F.) larvae, an edible insect in Nigeria. Afr Entomol 25:156-163. https://doi.org/10.4001/ 003.025 .0156

Omotoso OT, Adedire CO (2007) Nutrient composition, mineral content and the solubility of the proteins of palm weevil, Rhynchophorus phoenicis f. (Coleoptera: Curculionidae). J Zhejiang Univ Sci B 8: 318-322. https://doi.org/10.1631/jzus.2007.B0318

Payne CLR, Scarborough P, Rayner M, Nonaka K (2016) Are edible insects more or less 'healthy' than commonly consumed meats? A comparison using two nutrient profiling models developed to combat over- and undernutrition. Eur J Clin Nutr 70:285-291. https:// doi.org/10.1038/ejen.2015.149

Raheem D, Carrascosa C, Oluwole OB, Nieuwland M, Saraiva A, Millán R, Raposo A (2019) Traditional consumption of and rearing edible insects in Africa, Asia and Europe. Crit Rev Food Sci Nutr 59:2169 2188. https://doi.org/10.1080/10408398.2018.1440191

Ramandey E, van Mastrigt H (2010) Edible insects in Papua, Indonesia: from delicious snack to basic need. In: Durst PB, Johnson DV, Leslie $\mathrm{RN}$, Shono K (eds) Forest insects as food: humans bite back : proceedings of a workshop on Asia-Pacific resources and their potential for development, 19-21 February 2008, Chiang Mai, Thailand. FAO Regional Office for Asia and the Pacific, Bangkok, Thailand, pp $105-114$

Rigotti A (2007) Absorption, transport, and tissue delivery of vitamin E. Mol Asp Med 28:423-436. https://doi.org/10.1016/j.mam.2007.01. 002

Romano C, Corsetti G, Flati V, Pasini E, Picca A, Calvani R, Marzetti E, Dioguardi FS (2019) Influence of diets with varying essential / nonessential amino acid ratios on mouse lifespan. Nutrients 11. https:// doi.org/10.3390/nu11061367

Sen CK, Khanna S, Roy S (2006) Tocotrienols: vitamin E beyond tocopherols. Life Sci 78:2088-2098

Sirimungkararat S, Saksirirat W, Nopparat T, Natongkham A (2010) Edible products from eri and mulberry silkworms in Thailand. In: Durst PB, Johnson DV, Leslie RN, Shono K (eds) Forest insects as food: humans bite back: proceedings of a workshop on Asia-Pacific resources and their potential for development, 19-21 February 2008, Chiang Mai, Thailand. FAO Regional Office for Asia and the Pacific, Bangkok, Thailand, pp 189-200
Tommaseo-Ponzetta M, Paoletti MG (2005) Lessons from traditional foraging patterns in West Papua (Indonesia). In: Paoletti MG (ed) Ecological implications of minilivestock: role of rodents, frogs, snails and insects for sustainable development. Science Publishers, New Hampshire, pp 441-457

UN Department of Economic and Social Affairs, Population Division (2017) World population prospects: The 2017 revision, DVD edition

UNICEF Indonesia (2018) Health and nutrition: Challenges. https:// www.unicef.org/indonesia/health_nutrition_2851.html. Accessed 19 Aug 2018

van Huis A, Oonincx DGAB (2017) The environmental sustainability of insects as food and feed. A review. Agron Sustain Dev 37:1754. https://doi.org/10.1007/s13593-017-0452-8

van Huis A, Van Itterbeeck J, Klunder H, Mertens E, Halloran A, Muir G, Vantomme P (2013) Edible insects: future prospects for food and feed security. FAO forestry paper, vol 171 . FAO, Rome

WHO/FAO (2004) Vitamin and mineral requirements in human nutrition: report of a joint $\mathrm{FAO} / \mathrm{WHO}$ expert consultation, Bangkok, Thailand, 21-30 September 1998. Rome, Italy

Wiesner DL, Specht CA, Lee CK, Smith KD, Mukaremera L, Lee ST, Lee CG, Elias JA, Nielsen JN, Boulware DR, Bohjanen PR, Jenkins MK, Levitz SM, Nielsen K (2015) Chitin recognition via chitotriosidase promotes pathologic type- 2 helper $\mathrm{T}$ cell responses to cryptococcal infection. PLoS Pathog 11:e1004701. https://doi. org/10.1371/journal.ppat.1004701

Womeni HM, Linder M, Tiencheu B, Mbiapo FT, Villeneuve P, Fanni J, Parmentier M (2009) Oils of insects and larvae consumed in Africa: potential sources of polyunsaturated fatty acids. OCL 16:230-235. https://doi.org/10.1051/ocl.2009.0279

Womeni HM, Tiencheu B, Linder M, Martial E, Nabayo C, Tenyang N, Mbiapo FT, Villeneuve P, Fanni J, Parmentier M (2012) Nutritional value and effect of cooking, drying and storage process on some functional properties of Rhynchophorus phoenicis. Int J Life Sci Pharma Res 2:L203-L219

Publisher's note Springer Nature remains neutral with regard to jurisdictional claims in published maps and institutional affiliations. 